\title{
$\mathrm{MIA}$ 로 유발된 골관절염 동물모델에서 산수유 추출물의 골관절염 개선 효과
}

백경민 ${ }^{1}$, 안유민 ${ }^{1}$, 신미래 ${ }^{2}$, 김민주 ${ }^{2}$, 이진아 ${ }^{2}$, 노성수 ${ }^{2}$

${ }^{1}$ 대구한의대학교부속한방병원 심계내과학교실, ${ }^{2}$ 대구한의대학교 한의과대학 본초약리학교실

\section{Protective Effect of Corni Fructus Extracts on MIA-induced Animal Model of Osteoarthritis: Effect of Corni Fructus Extracts on OA}

\author{
Kyungmin Baek ${ }^{1}$, Yu-min An ${ }^{1}$, Mi-Rae Shin², Min Ju Kim², Jin A Lee², Seong-Soo Roh ${ }^{2}$ \\ 'Dept. of Cardiovascular and Neurologic Diseases of Korean Internal Medicine, \\ Daegu Korean Medicine Hospital of Daegu Haany University \\ ${ }^{2}$ Dept. of Herbology, College of Korean Medicine, Daegu Haany University
}

\begin{abstract}
Objectives: Osteoarthritis $(\mathrm{OA})$ is a chronic and degenerative joint disease characterized by progressive degeneration of articular cartilage. Inflammation is a recognized and important factor of $\mathrm{OA}$ progression. The present study was designed to investigate the protective effect of Corni Fructus water extract (CFW) on a monosodium iodoacetate (MIA)-induced rat model of OA.

Methods: Osteoarthritis was induced by injection of MIA ( $50 \mu \mathrm{L} ; 80 \mathrm{mg} / \mathrm{mL})$ into the knee joint cavity of rats. After an adaptation period for seven days, the rats were divided into 4 groups $(n=8 /$ group $)$ : normal, control, indomethacin-treated (5 $\mathrm{mg} / \mathrm{kg}$ ), and CFW-treated $(200 \mathrm{mg} / \mathrm{kg}$ ) groups. The rats were treated orally for 14 days. Pain was evaluated by determining hind paw weight distribution. For biochemical analyses, we measured the changes in reactive oxygen species (ROS) and peroxynitrite $\left(\mathrm{ONOO}^{-}\right)$in the knee joint. The presence of anti-oxidant proteins and inflammatory proteins was determined by western blotting.

Results: The administration of CFW significantly improved the hind paw weight distribution. The ROS and $0 \mathrm{NOO}^{-}$levels of knee joint were significantly decreased in the CFW group. CFW inhibited the production of inflammatory mediators, such as COX-2, and inflammatory cytokines, including IL-6 and IL-1 $\beta$, via the NF- $\kappa$ B signaling pathway. The expression of anti-oxidant enzymes, such as catalase and GPx-1/2 also increased significantly.
\end{abstract}

Conclusions: The findings indicate that $\mathrm{CFW}$ has a therapeutic and protective effect on $\mathrm{OA}$ by suppression of inflammation. Therefore, CFW could represent a potential and effective candidate for OA treatment.

Key words: monosodium iodoacetate, osteoarthritis, Corni Fructus, inflammation, NF- $\mathrm{BBp} 65$

\section{I. 서 론}

· 투고일 : 2020.01.06, 심사일: 2020.02.06, 게재확정일: 2020.02 .07

- Corresponding author: Seong-soo Roh College of Korean Medicine, Daegu Haany University, 136, Sincheondong -ro, Suseong-gu, Daegu, Republic of Korea TEL: +82-53-770-2351 FAX: +82-53-768-6340 E-mail: ddede@dhu.ac.kr
골관절염은 관절 주변 및 관절 내 연골의 과다 생성, 관절 연골의 파괴, 관절의 변형 등을 특징으 로 하는 퇴행성 관절 질환 ${ }^{1}$ 으로 염증과 통증을 유 
발하여 운동장애를 초래하고 삶의 질을 저하시킨 다. 골관절염의 원인은 잘 알려져 있지는 않지만 연골 합성과 분해의 생리학적 불균형에 따른 항상 성의 붕괴로 여겨지고 있으며 ${ }^{2}$ 관절에 만성 통증과 기능적 손실을 유발하는 $\mathrm{OA}$ 의 관절 연골 파괴는 염증성 사이토카인의 과도한 생산을 포함한 다양 한 요인에 의해 유발된다고 알려져 있다 ${ }^{3.4}$. 그 외 노화가 골관절염의 발달에 중요한 위험 요인 중 하나로 알려져 있으며 많은 연구에서 나이가 증가 함에 따라 손, 엉덩이, 척추 및 무릎 골관절염이 증 가하는 것으로 보고되었다. ${ }^{5}$ 2008년 우리나라의 65 세 이상의 노인 인구는 약 507만 명이었으나 꾸준 히 증가하여 2017년에는 $3.8 \%$ 의 증가세를 보였으 며 ${ }^{6}$, 이는 우리나라가 고령화 사회로 진입하고 있 음을 보여주는 지표로 파악할 수 있다. 이에 따라 골관절염 유병률은 계속적으로 증가할 것으로 예 상되어 노년기 건강 및 삶의 질 개선을 위한 예방 관리의 중요성이 대두되고 있다.

골관절염의 일반적인 치료방법으로는 장기적인 약물요법, 물리요법, 수술요법 또는 주사치료 등이 있으나 위장관 장애, 간기능 및 신장 기능 장애의 부작용, 염증 재발 등의 부작용에 대한 부담과 골 관절염으로 인한 사회경제적 비용이 증가되면서 ${ }^{8}$ 예방 및 진행 억제를 위한 효과적인 치료방법에 대한 다양한 연구(약재, 한약, 약침 등)가 진행되 고 있다 ${ }^{9-15}$.

山荣莫 (Cornus officinalis Sieb. et. Zucc.)는 층층 나무과(Cornaceae)에 속하는 낙엽소교목인 산수유 나무의 성숙한 과실을 건조한 약재이다. 味는 酸涉 하고, 性은 微溫하며 補益肝腎, 澀精固脫 등의 효 능이 있는 것으로 알려져 있다. 山茱英의 주요 성분 은 triterpene 계열인 saponin, ursolic acid, stearic acid, linolenic acid, palmitic acid, oleic acid, morroniside, loganin, valine, tyrosine 등이 알려져 있으며 ${ }^{16}$, 山 茱葫의 생리 활성으로 항염증 ${ }^{17}$, 혈관 이완 ${ }^{18}$, 골다 공증 억제 ${ }^{19}$, 체중 감소 ${ }^{20}$, 항산화 ${ }^{21}$, 항당뇨 ${ }^{22}$, 항지질 효과 $^{23}$, 인지력향상 ${ }^{24}$ 등의 효과가 보고되었다.
한의학에서 골관절염은 痺證의 범주로 인식되 며, 病因은 크게 外因인 風, 寒, 濕 邪氣로 인한 경 우와 內因인 관절에 직접적인 영양을 제공하는 肝 腎의 虛로 인한 경우로 보고되고 있다 ${ }^{25}$. 임상적으 로는 祛風寒濕 약물과 補肝腎약물을 겸하여 처방 하는 경우가 많고 실제 많은 환자들이 골관절염의 통증관리에 한의학적 치료를 이용하고 있다.

山荣䓎는 補监肝腎의 효능이 있어 노인, 만성질 환에 빈용되는 약물로 골다공증 억제 효과에 대한 세포 및 동물 모델 연구는 활발히 진행 중이나, 골 관절염에 대한 효과는 실험적 연구를 통해 밝혀진 바가 없다. 이에 본 연구는 MIA로 골관절염을 유 발한 rat 모델에서 산수유 물추출물을 경구 투여하 여 관절 조직의 항산화 및 항염증 효과를 관찰한 후 유의한 결과를 얻었기에 보고하는 바이다.

\section{II. 재료 및 방법}

\section{1. 실험동물}

7주령의 Sprague-Dawley(SD) 계 체중 $180 \sim 220 \mathrm{~g}$ 의 수컷 흰쥐를 하나바이오테크(경기, 한국)에서 구입하여, 물과 고형사료(조단백질 $18 \%$ 이상, 칼륨 $0.55 \%$ 이상, 조지방 $5.0 \%$ 이상, 조회분 $8.0 \%$ 이하, 칼슘 $1.0 \%$ 이상, 인 $0.85 \%$ 이상, 나트륨 $0.25 \%$ 이상, 조섬유 $5.0 \%$ 이하, 마그네슘 $0.15 \%$ 이상 $\mathrm{NIH}-41$, Zeigler Bros, Inc., USA)를 충분히 공급하며 1주일 간 실험실 환경에 적응시킨 후 실험에 사용하였다. 동물 사육실의 조건은 conventional system으로 명 암주기는 12 시간 주기, 온도 $22 \pm 2{ }^{\circ} \mathrm{C}$, 습도 $50 \pm 5 \%$ 로 조절하였다. 대구한의대학교 동물 실험 윤리위 원회의 승인(DHU2019-048)을 얻어 실험을 시행하 였으며 동물관리 규정을 준수하였다.

\section{2. 시료 추출}

본 실험에 사용한 山茱英는 옹기한약국(대구, 한국)에서 구입하여 대구한의대 본초약리학교실에 서 정선, 감별하여 사용하였다. 山茉榦 $300 \mathrm{~g}$ 에 10 
배수의 증류수 $3 \mathrm{~L}$ 를 가하여 열탕 추출기를 사용 하여 2시간 열수 추출을 시행하였다. 추출물을 여 과하여 여과액을 감압 추출장치로 농축한 후 동결 건조기에서 완전히 건조시켜 $77.1 \mathrm{~g}$ 의 파우더를 얻 었으며 수율은 $25.7 \%$ 였다. 얻은 파우더를 냉동 $\left(-80{ }^{\circ} \mathrm{C}\right)$ 보관하여 실험 직전에 증류수에 희석하여 사용하였으며 이를 CFW(Corni Fructus water extract) 라고 하였다.

\section{3. 시 약}

본 실험에 사용된 potassium persulfate, phenyl methyl sulfonyl fluoride(PMSF), monosodium iodoacetate(MIA), indomethacin, dithiothreitol(DTT) 는 Sigma Aldrich Co., Ltd.(St. Louis, MO, USA) 에서, 2',7'-dichlorofluorescein diacetate(DCF-DA) 와 Dihydrorhodamine 123는 Molecular Probes (Eugene, OR, U.S.A.)에서 구입하였다. 1차 항체 nuclear factor-kappa Bp65(NF-kBp65), cyclooxygenase-2 (COX-2), inducible nitric oxide synthase(iNOS), interleukin-6(IL-6), tumor necrosis factor-alpha (TNF- $\alpha$ ), interleukin-1 $\beta(\mathrm{IL}-1 \beta)$, superoxide dismutase (SOD), catalase, glutathione peroxidase $-1 / 2(\mathrm{GPx}-1 / 2)$, $\beta$-actin, histone 및 2차 항체는 Santa Cruz Biotechnology (Santa Cruz, CA, USA)에서 구입하 였다. Protease inhibitor mixture, Ethylene diamine tetra acetic acid(EDTA)는 Wako Pure Chemical Industries, Ltd.(Osaka. Japan)에서 구입하였으며, Nitrocellulose membranes는 Amersham GE Healthcare (Buckinghamshire, UK)에서 구입하였다. 단백질 정량을 위한 $\mathrm{BCA}$ protein assay kit는 Thermo Scientific(Waltham, MA, USA)에서 구입하였다.

\section{4. 산수유 추출물의 $\mathrm{HPLC}$ 분석 조건 및 결과}

메탄올 $100 \mathrm{~mL}$ 에 산수유 $2 \mathrm{~g}$ 를 넣어 환류냉각 기를 달고 수욕에서 2 시간 가온하여 식힌 다음 여 과하고, 잔여물에 다시 메탄올 $100 \mathrm{~mL}$ 를 넣어 환 류냉각기를 달고 수욕에서 2시간 가온하여 식힌
다음 여과하였다. 여과한 여액을 전부 합하여 감압 농축한 다음 메탄올을 넣어 $50 \mathrm{~mL}$ 로 정확히 맞춘 후 syringe filter로 다시 여과하여 검액으로 사용하 였다. Column은 Waters Xbridge C18 column(4.6 $\mathrm{mm} \times 250 \mathrm{~mm}, 5 \mu \mathrm{m})$ 을 $25{ }^{\circ} \mathrm{C}$ 로 유지시켜 사용하였 다. 유속은 $0.5 \mathrm{~mL} / \mathrm{min}$ 으로 하였고 $10 \mu \mathrm{l}$ 를 주입하 여 Waters Alliance e2695(Waters Corp., Milford, USA)의 Waters $2489 \mathrm{UV}$ detector $240 \mathrm{~nm}$ 에서 검 출하였다. 이동상은 희석시킨 아세트산(0.1->100), 아세토니트릴, 메탄올 $85: 10: 5)$ 로 혼합하여 사용하 였다. 표준품은 식품의약품안전처 Loganin-2006을 사용하였으며, $0.8 \mathrm{mg}$ 을 메탄올 $4 \mathrm{~mL}$ 에 녹여 사용 하였다. HPLC를 이용한 정량 분석 결과 loganin 함량은 $5.7 \mathrm{mg} / \mathrm{g}$ 으로 나타났다.

\section{5. 골관절염 효능 평가}

1) 골관절염 유발

실험동물의 오른쪽 무릎 주변의 털을 깨끗이 제 모한 후, $0.9 \%$ saline으로 희석한 MIA를 $0.3 \mathrm{ml}$ insulin 주사기(BD 31 G Ultra-Fine II. USA)를 사 용하여 오른쪽 무릎 관절강 내에 $50 \mu \mathrm{l}(80 \mathrm{mg} / \mathrm{mL})$ 씩 주입하여 골관절염을 유발하였다.

2) 군 분리 및 약물투여

$\mathrm{MIA}$ 로 유발 7일 후 뒷다리 체중 부하 검사를 통 해 골관절염이 유발된 실험동물을 각 군당 8 마리씩 4 그룹으로 구분하여 실험을 진행하였다. 실험군은 골관절염을 유발하지 않은 정상군(Normal), 골관절 염 유발 후 증류수를 투여한 대조군(Control), 골관 절염 유발 후 indomethacin을 $5 \mathrm{mg} / \mathrm{kg}$ 로 경구 투 여한 양성대조군(INDO), 골관절염 유발 후 CFW 를 $200 \mathrm{mg} / \mathrm{kg}$ 로 경구 투여한 $\mathrm{CFW}$ 군 $(\mathrm{CFW})$ 으로 약물은 2주간 존대(Zonde)를 이용하여 투여하였다.

3) 체중 측정

실험동물의 체중은 전자체중계로 1 회/2일으로 동일 조건에서 측정하였다.

4) 뒷다리 체중 부하 측정

뒷다리 체중 부하는 MIA로 골관절염을 유발하기 7 
일 전(-1 week), 유발 후 7일(0 week), 14일(1 week), 21일 (2 weeks) 총 4번을 측정하였다. Incapacitance tester(Ser No. 01/45/25, Linton instrument Co., $\mathrm{UK})$ 를 이용하여 오른쪽, 왼쪽 뒷다리 부하 무게를 측정하였다. 뒷다리 체중 부하 측정 결과는 골관절 염이 유발된 오른쪽 뒷다리의 체중 부하량에 정상 적인 왼쪽 뒷다리 부하량을 계산하여 체중 부하 비율을 계산하였다. 정상군의 체중 부하 비율에 각 군의 체중 부하 비율을 계산한 후 평균표준편차 로 나타내었으며, 다음의 식을 이용하였다.

$\int$ 체중부하비율 $=$

정상뒷다리의 체중 부하량

관절염이 유발된 뒷다리의 체중 부하량

$\iint$ 상대적 체중 부하 $=$

$\frac{\text { 각 군의 체중 부하 비율 }}{\text { 정상군의 평균 체중 부하 비율 }} \times 100$

5) 관절 조직내 산화적 스트레스 바이오마커 측정

관절조직은 $1 \mathrm{mM}$ EDTA-50 mM sodium phosphate buffer(pH 7.4)를 이용하여 분쇄하였다. Ali et $a .^{26}$ 방법을 이용하여 ROS를 측정하였으며 $25 \mathrm{mM} \mathrm{DCF}-\mathrm{DA}$ 를 혼합한 후, 형광 광도계를 이 용하여 0 분부터 매 10 분씩 emission wavelength of $530 \mathrm{~nm}$ 와 excitation wavelength of $486 \mathrm{~nm}$ 를 이용 하여 30 분간 측정한 산출 값을 계산하였다. 관절조 직의 $\mathrm{ONOO}^{-}$측정을 위해 Kooy et al. ${ }^{27)}$ 방법을 이 용하여 측정하였다.

6) 관절조직 Western blotting

2주간의 약물 투여가 끝난 뒤 오른쪽 무릎 부위 를 절단하여 관절조직을 채취한 다음 관절 조직의 세포질 분획을 획득하기 위해 $100 \mathrm{mM}$ Tris- $\mathrm{HCl}$ ( $\mathrm{pH}$ 7.4), $2 \mathrm{mM} \mathrm{MgCl}, 5 \mathrm{mM}$ Tris- $\mathrm{HCl}(\mathrm{pH} 7.5$ ), $15 \mathrm{mM} \mathrm{CaCl}_{2}, 1.5 \mathrm{M}$ sucrose, protease inhibitor cocktail, $0.1 \mathrm{M} \mathrm{DTT}$ 를 첨가시킨 buffer A를 넣은 후 tissue grinder(Bio Spec Product, USA)를 사용 해 분쇄한 다음 $10 \% \mathrm{NP}-40$ 용액을 첨가하였다. 아이스 위에서 20 분간 방치한 후, $12,000 \mathrm{rpm}$ 으로 2 분간 원심분리하여 세포질을 함유한 상층액을 분
리하였다. 핵 분획을 얻기 위해 $10 \% \mathrm{NP}-40$ 가 더해 진 buffer $\mathrm{A}$ 에 두 번 헹구고 $100 \mu \mathrm{l}$ 의 buffer $\mathrm{C}$ (50 mM HEPES, $50 \mathrm{mM} \mathrm{KCl,} 0.3 \mathrm{mM} \mathrm{NaCl}, 0.1 \mathrm{mM}$ EDTA, $1 \mathrm{mM}$ DTT, $0.1 \mathrm{mM}$ PMSF, 10\% glycerol) 를 첨가해 재부유시킨 후 10 분마다 vortex를 3 번 하였다. $4{ }^{\circ} \mathrm{C}$ 에서 $12,000 \mathrm{rpm}$ 으로 10 분간 원심 분리 한 후 핵을 포함하고 있는 상층액을 얻어 $-80{ }^{\circ} \mathrm{C}$ 에 서 각각 냉동 보관하였다. 세포질 내의 $\mathrm{COX}-2$, iNOS, IL-6, TNF- $a$, IL-13, SOD, catalase, GPx-1/2, $\beta$-actin의 단백질 발현을 평가하기 위해 8 15\% SDS-polyacrylamide gel을 만들어 $10 \mu \mathrm{g}$ 의 단백질 을 전기영동하고 acrylamide gel을 nitrocellulose membrane으로 이동시켰다. 단백질이 전이된 membrane 에 보고자하는 1 차 항체를 처리하여 $4{ }^{\circ} \mathrm{C}$ 에서 overnight 시켰으며, 그 후 PBS-T로 6 분마다 5회 헹구고, 1차 항체에 적합한 2차 항체 $(\mathrm{PBS}-\mathrm{T}$ 로 1:3000로 희석해 서 사용)를 사용하여 상온에서 2시간 반응시킨 후, PBS-T로 6분마다 8회 세척하였다. 그리고 enhanced chemiluminescence(ECL) 용액에 노출시킨 다음, Sensi-Q2000 Chemidoc(Lugen Sci Co., Ltd., 경기 도, 한국)에 감광시켜 단백질 발현을 확인한 후, 해 당 band를 ATTO Densitograph Software(ATTO Corporation, Tokyo, Japan)프로그램을 사용하여 정량하였다. 각 그룹의 단백질 수준은 정상군의 단 백질 수준으로 나누어 상대적 비로 나타내었다.

\section{6. 통계분석}

모든 수치는 평균과 표준편차 $(\operatorname{mean} \pm \mathrm{SD})$ 로 표 시하였으며, SPSS(Version 22.0, IBM, Armonk, NY, USA)를 사용하여 one-way analysis of variance (ANOVA) test를 실시한 후 least-significant differences (LSD) test로 사후검증을 실시하여 각 군의 평균 차이에 대한 통계적 유의성을 $\mathrm{p}$-value<0.05에서 검 증하였다. 


\section{III. 결 과}

\section{1. 체중변화량}

골관절염 유발 후 2 주간의 약물투여 기간 동안 측정된 체중변화량은 정상군 $62.36 \pm 6.64 \mathrm{~g}$, 대조군 $60.11 \pm 7.60 \mathrm{~g}$, Indo군 $60.11 \pm 7.60 \mathrm{~g}$, CFW군 $62.33 \pm$ $9.75 \mathrm{~g}$ 으로 각 군간의 유의성은 나타나지 않았다 (Fig. 1, Table 1).

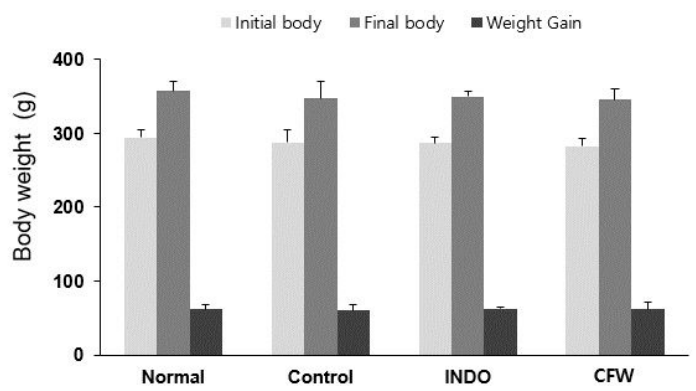

Fig. 1. Change of body weight.

Table 1. Change of Body Weight

\begin{tabular}{cccc} 
Group & $\begin{array}{c}\text { Initial body } \\
\text { weight }(\mathrm{g})\end{array}$ & $\begin{array}{c}\text { Final body } \\
\text { weight }(\mathrm{g})\end{array}$ & $\begin{array}{c}\text { Body weight } \\
\text { gain }(\mathrm{g})\end{array}$ \\
\hline Normal & $294.64 \pm 9.83$ & $357.00 \pm 13.79$ & $62.36 \pm 6.64$ \\
Control & $287.33 \pm 17.06$ & $347.44 \pm 23.28$ & $60.11 \pm 7.60$ \\
IND 0 & $287.17 \pm 7.25$ & $349.67 \pm 7.32$ & $62.50 \pm 2.24$ \\
CFW & $282.89 \pm 10.52$ & $345.22 \pm 15.19$ & $62.33 \pm 9.75$ \\
\hline All data are expressed means $\pm S D(\mathrm{n}=8)$. \\
Normal : normal rats, Control : MIA-induced osteoarthritis \\
rats, IND0 : MIA-induced osteoarthritis rats treated with \\
indomethacin 5 mg/kg body weight, CFW : MIA-induced \\
osteoarthritis rats treated with Corni Fructus water \\
extract 200 mg/kg body weight
\end{tabular}

\section{2. 뒷다리 체중 부하 측정 결과}

뒷다리 체중 부하는 골관절염을 유발하기 7일 전(-1 week), 유발 후 7일 (0 week), 14일 (1 week), 21일(2 weeks) 총 4번을 측정하였다. 정상군의 뒷 다리 체중 부하 비율을 100 으로 하였을 때, 각 군 의 상대적 뒷다리 체중 부하의 변화를 측정한 결 과. MIA 유발 7일 후에는 대조군 233.05 \pm 21.11 , $\mathrm{IND} 0$ 군 225.19 $\pm 18.55, \mathrm{CFW}$ 군 $227.08 \pm 15.72$ 로 각 군 간의 유의한 차이는 없었다. 그러나 MIA 투여

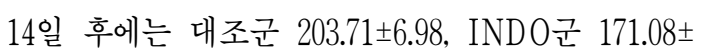
15.89 ( $p<0.05), \mathrm{CFW}$ 군 $165.49 \pm 11.80$ ( $p<0.05$ )로 나타 나 INDO군과 CFW군에서 뒷다리 체중 부하가 대 조군에 비해 유의하게 감소하였다. 21일 후에는 대 조군 204.23 \pm 12.44 , Indo군 $142.14 \pm 9.86(p<0.01$ ), CFW 군 $151.95 \pm 8.50(p<0.01)$ 로 나타나 IND0군과 $\mathrm{CFW}$ 군 모두 대조군에 비해 유의하게 감소하였다(Fig. 2, Table 2).

\section{3. 산화적 스트레스 바이오마커 측정 결과}

산화적 스트레스 바이오마커 측정을 위하여 관 절조직의 $\mathrm{ROS}, \mathrm{ONOO}^{-}$를 측정하였다. $\mathrm{ROS}$ (fluorescence $/ \mathrm{min} / \mathrm{mg}$ protein) 생성량 측정 결과, 대조군은 $168,978 \pm 22,555$ 로 정상군 $58,454 \pm 16,268$ 에 비하여 유의하게 증가하였다 $(p<0.001)$. 양성 대조

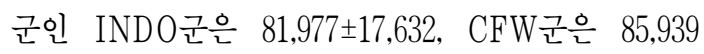
$\pm 21,286$ 로 대조군에 비하여 유의하게 감소한 것을 확인하였다( $p<0.01)$. $0 \mathrm{NOO}^{-}$(fluorescence/mg protein) 생성량을 측정한 결과, 대조군은 $37,420 \pm 1,280$ 로 정 상군 $19,751 \pm 2,502$ 에 비해 유의하게 증가한 것을 확 인할 수 있었다 $(p<0.001)$. 양성 대조군인 IND0군 $19,678 \pm 2,389$ 과 CFW군 $17,582 \pm 2,927$ 은 대조군에 비 하여 유의하게 감소하였다( $p<0.001)$ (Fig. 3). 


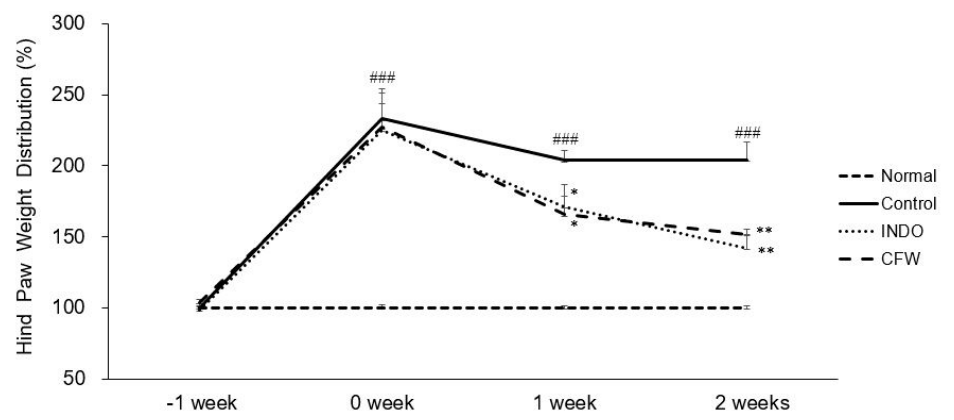

Fig. 2. The changes in relative hind paw weight distribution in MIA-induced osteoarthritis rats.

All data are expressed means \pm SD $(n=8)$.

Significance : ${ }^{*} p<0.05$, ${ }^{* *} p<0.01$ vs. control group and ${ }^{\# \# ~} p<0.001$ vs. normal group

Normal : normal rats, Control : MIA-induced osteoarthritis rats, IND0 : MIA-induced osteoarthritis rats treated with indomethacin $5 \mathrm{mg} / \mathrm{kg}$ body weight, CFW : MIA-induced osteoarthritis rats treated with Corni Fructus water extract $200 \mathrm{mg} / \mathrm{kg}$ body weight

Table 2. The Changes in Relative Hind Paw Weight Distribution in MIA-induced Osteoarthritis Rats

\begin{tabular}{|c|c|c|c|c|}
\hline Group & -1 week (g) & 0 week $(\mathrm{g})$ & 1 week $(\mathrm{g})$ & 2 weeks $(\mathrm{g})$ \\
\hline Normal & $100.00 \pm 3.74$ & $100.00 \pm 2.07$ & $100.00 \pm 1.39$ & $100.00 \pm 1.86$ \\
\hline Control & $99.91 \pm 1.86$ & $233.05 \pm 21.11$ \#\# & $203.71 \pm 6.98$ \#\# & $204.23 \pm 12.44$ \#\#\# \\
\hline INDO & $98.65 \pm 2.17$ & $225.19 \pm 18.55$ & $171.08 \pm 15.89^{*}$ & $142.14 \pm 9.86^{* *}$ \\
\hline CFW & $103.98 \pm 3.02$ & $227.08 \pm 15.72$ & $165.49 \pm 11.80^{*}$ & $151.95 \pm 8.50^{* *}$ \\
\hline
\end{tabular}

All data are expressed means \pm SD $(n=8)$.

Significance : ${ }^{*} p<0.05,{ }^{* *} p<0.01$ vs. control group and ${ }^{\# \# \# ~} p<0.001$ vs. normal group

Normal : normal rats, Control : MIA-induced osteoarthritis rats, INDO : MIA-induced osteoarthritis rats treated with indomethacin $5 \mathrm{mg} / \mathrm{kg}$ body weight, CFW : MIA-induced osteoarthritis rats treated with Corni Fructus water extract $200 \mathrm{mg} / \mathrm{kg}$ body weight
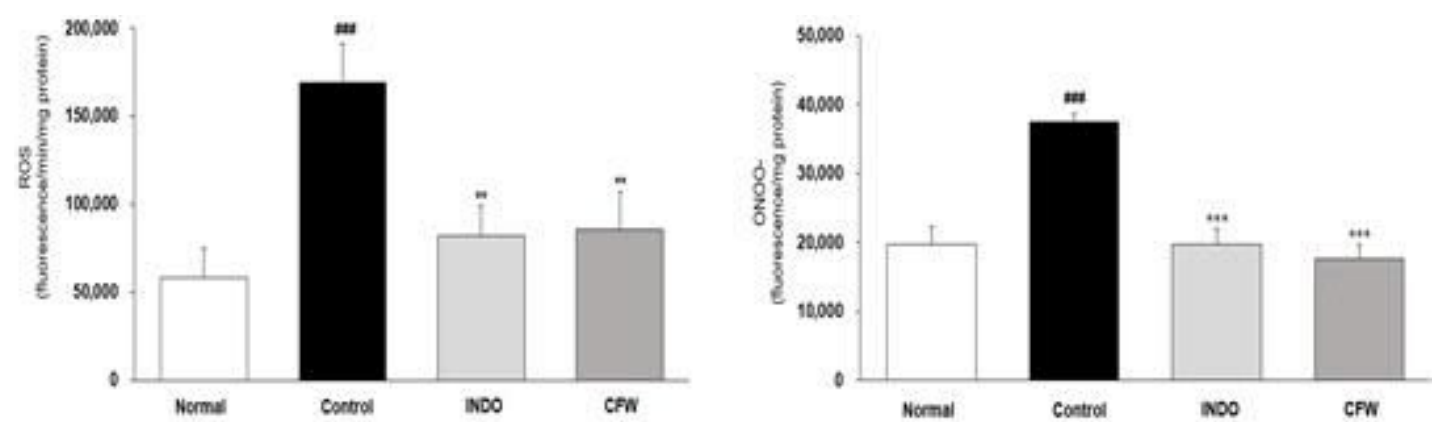

Fig. 3. Oxidative stress biomarker in knee joint.

All data are expressed means \pm SD $(n=8)$.

Significance : ${ }^{* *} p<0.01,{ }^{* * *} p<0.001$ vs. control group and ${ }^{\# \#} p<0.001$ vs. normal group

Normal : normal rats, Control : MIA-induced osteoarthritis rats, INDO : MIA-induced osteoarthritis rats treated with indomethacin $5 \mathrm{mg} / \mathrm{kg}$ body weight, CFW : MIA-induced osteoarthritis rats treated with Corni Fructus water extract $200 \mathrm{mg} / \mathrm{kg}$ body weight 
4. 관절조직 내 항산화 단백질 발현량 분석

Western blot으로 관절조직에서 항산화 효소 단 백질인 SOD, catalase, $\mathrm{GPx}-1 / 2$ 의 발현량을 분석 하였다. $\mathrm{SOD}$ 의 발현량을 측정한 결과, 대조군은 $0.87 \pm 0.01$ 로 정상군 $1.00 \pm 0.03$ 에 비하여 유의적으로 낮게 발현하였다( $p<0.01)$. 양성대조군인 IND0군은 $0.95 \pm 0.05$, CFW군 $0.97 \pm 0.05$ 로 대조군 대비 증가하 였다. Catalase 단백질 발현량을 측정한 결과, 대조
군 $0.62 \pm 0.06$ 으로 정상군 $1.00 \pm 0.08$ 에 비해 유의하게 감소하였다 $(p<0.01)$. 양성대조군인 IND0군 $0.88 \pm 0.06$, $\mathrm{CFW}$ 군 $0.78 \pm 0.07$ 로 대조군 대비 유의하게 증가하 였다 $(p<0.01, p<0.05) . \mathrm{GPx}-1 / 2$ 단백질 발현량을 측 정한 결과, 대조군 $0.58 \pm 0.04$ 은 정상군 $1.00 \pm 0.07$ 에 비해 유의하게 감소하였으며 $(p<0.001)$, 양성대조군 인 IND0군에서는 $0.88 \pm 0.09, \mathrm{CFW}$ 군 $0.82 \pm 0.10$ 은 대 조군에 비해 유의하게 증가하였다 $(p<0.05)$ (Fig. 4).
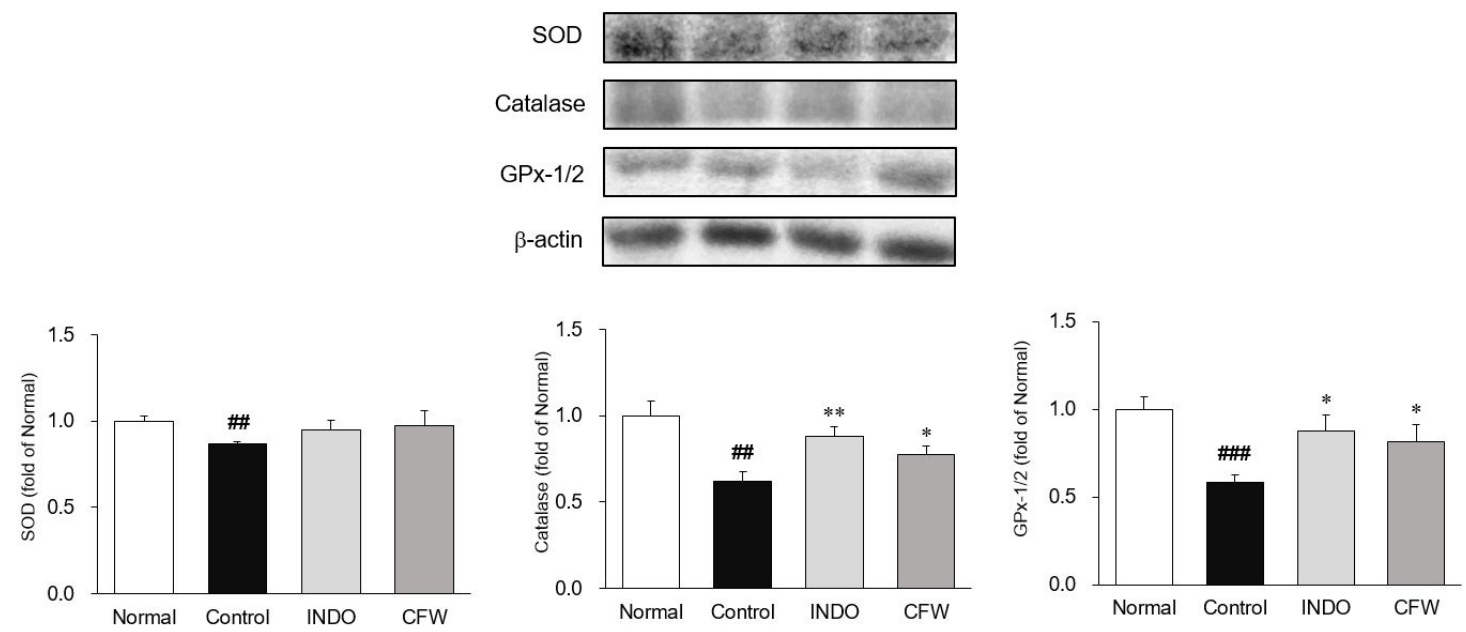

Fig. 4. Expression of anti-oxidant related proteins in knee joint.

All data are expressed means $\pm \mathrm{SD}(\mathrm{n}=8)$.

Significance : ${ }^{*} p<0.05,{ }^{* *} p<0.01$ vs. control group and ${ }^{\# \#} p<0.01$, ${ }^{\# \#} p<0.001$ vs. normal group

Normal : normal rats, Control : MIA-induced osteoarthritis rats, INDO : MIA-induced osteoarthritis rats treated with indomethacin $5 \mathrm{mg} / \mathrm{kg}$ body weight, CFW : MIA-induced osteoarthritis rats treated with Corni Fructus water extract $200 \mathrm{mg} / \mathrm{kg}$ body weight

\section{5. 관절조직 내 염증성 단백질 발현량 분석}

Western blot으로 관절조직에서 염증성 단백질 인 NF- $\mathrm{Bp} 65, \mathrm{COX}-2$, iNOS의 발현량을 분석하였 다. NF-kBp65 단백질 발현량을 측정한 결과, 대조 군 $1.16 \pm 0.10$ 로 정상군 $1.00 \pm 0.11$ 에 비해 증가하였 다. 양성대조군인 IND0군은 $0.93 \pm 0.11$ 로 대조군에 비해 감소하였다. 하지만 $\mathrm{CFW}$ 군은 $0.70 \pm 0.08$ 로 대 조군에 비해 유의하게 감소하였다( $p<0.01)$. $\mathrm{COX}-2$ 단백질 발현량을 측정한 결과, 대조군 $1.88 \pm 0.09$ 로
정상군 $1.00 \pm 0.11$ 에 비해 유의하게 증가하였다 $(p<$ 0.001 ). 양성 대조군인 IND 0군은 $1.25 \pm 0.17, \mathrm{CFW}$ 군 $1.23 \pm 0.13$ 로 대조군에 비해 유의하게 감소하였다 $(p<0.01, p<0.001)$. iNOS 단백질 발현량을 측정한 결과, 대조군 $1.33 \pm 0.14$ 로 정상군 $1.00 \pm 0.06$ 에 비해 유의하게 증가하였다 $(p<0.05)$. 양성대조군인 IND0 군은 $0.98 \pm 0.08$ 로 대조군에 비해 유의하게 감소하 였으며 $(p<0.05), \mathrm{CFW}$ 군 $1.09 \pm 0.06$ 으로 대조군에 비 해 감소하는 경향을 보였다(Fig. 5). 


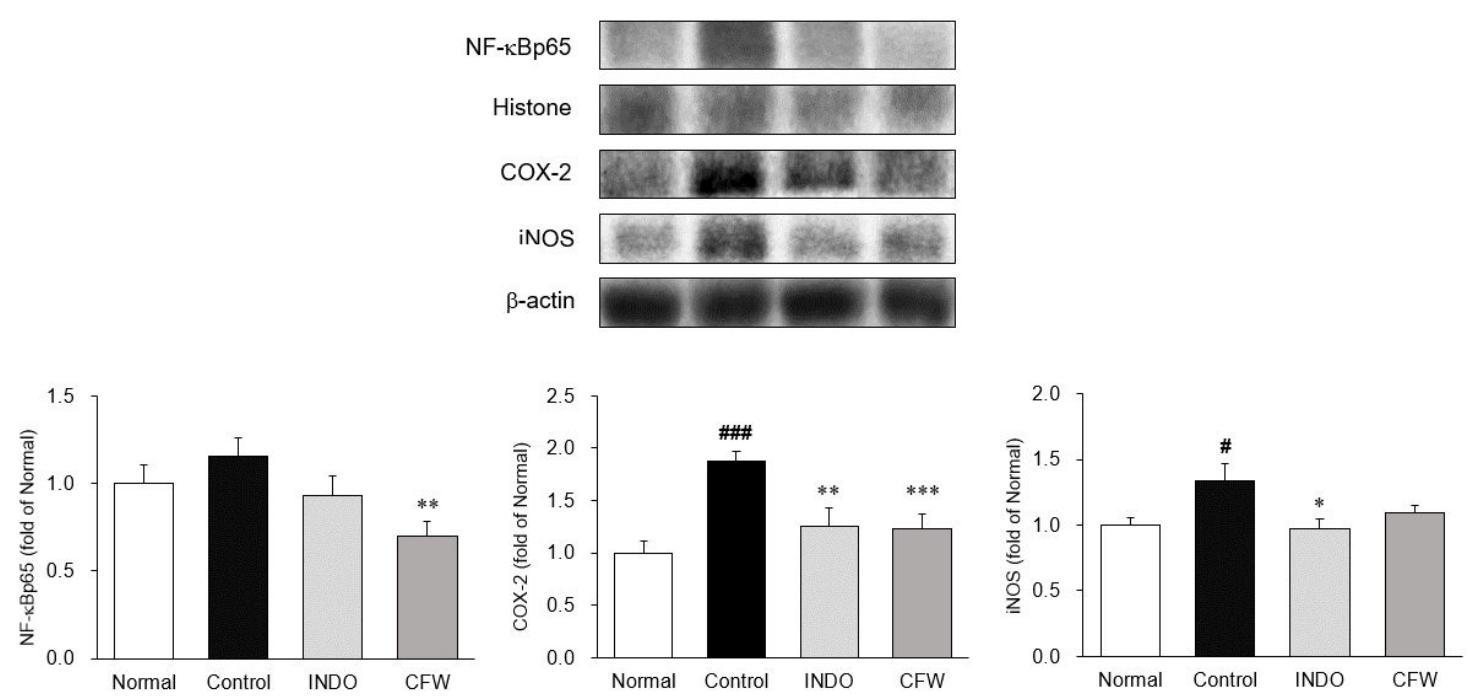

Fig. 5. Expression of inflammatory related proteins in knee joint.

All data are expressed means \pm SD $(n=8)$.

Significance : ${ }^{*} p<0.05,{ }^{* *} p<0.01,{ }^{* * *} p<0.001$ vs. control group and ${ }^{\#} p<0.05$, \#\#\# $p<0.001$ vs. normal group

Normal : normal rats, Control : MIA-induced osteoarthritis rats, IND0 : MIA-induced osteoarthritis rats treated with indomethacin $5 \mathrm{mg} / \mathrm{kg}$ body weight, CFW : MIA-induced osteoarthritis rats treated with Corni Fructus water extract $200 \mathrm{mg} / \mathrm{kg}$ body weight

6. 관절조직 내 염증성 사이토카인 발현량 분석

Western blot으로 관절조직에서 염증성 사이토 카인 TNF-a, IL-6, IL-1ß의 발현량을 측정한 결 과, 대조군은 $1.52 \pm 0.17$ 으로 정상군은 $1.00 \pm 0.04$ 에 대비하여 유의하게 증가하였다( $p<0.05)$. 양성대조 군인 IND0군은 $0.99 \pm 0.10$ 로 대조군에 비해 유의하 게 감소하였다 $(p<0.05)$. CFW군은 $1.34 \pm 0.11$ 로 감소 하였으나 유의하지는 않았다. IL-6 발현량을 측정 한 결과, 대조군은 $1.50 \pm 0.09$ 로 정상군 $1.00 \pm 0.06$ 에
비하여 유의적으로 높게 발현하였다( $p<0.001)$. 양성 대조군인 IND0군은 $1.04 \pm 0.10, \mathrm{CFW}$ 군은 $1.09 \pm 0.10$ 로 대조군에 비하여 유의하게 감소하였다( $p<0.01)$. IL- $1 \beta$ 발현량을 측정한 결과, 대조군은 $1.53 \pm 0.11$ 로 정상 군 $1.00 \pm 0.09$ 에 비하여 유의하게 증가하였다 $(p<0.01)$. 양성대조군인 IND 0군은 $1.07 \pm 0.08$ 로, $\mathrm{CFW}$ 군은 1.14 \pm 0.14 로 대조군에 비해 유의하게 감소하였다 $(p<0.01$, $p<0.05$, reps) (Fig. 6). 

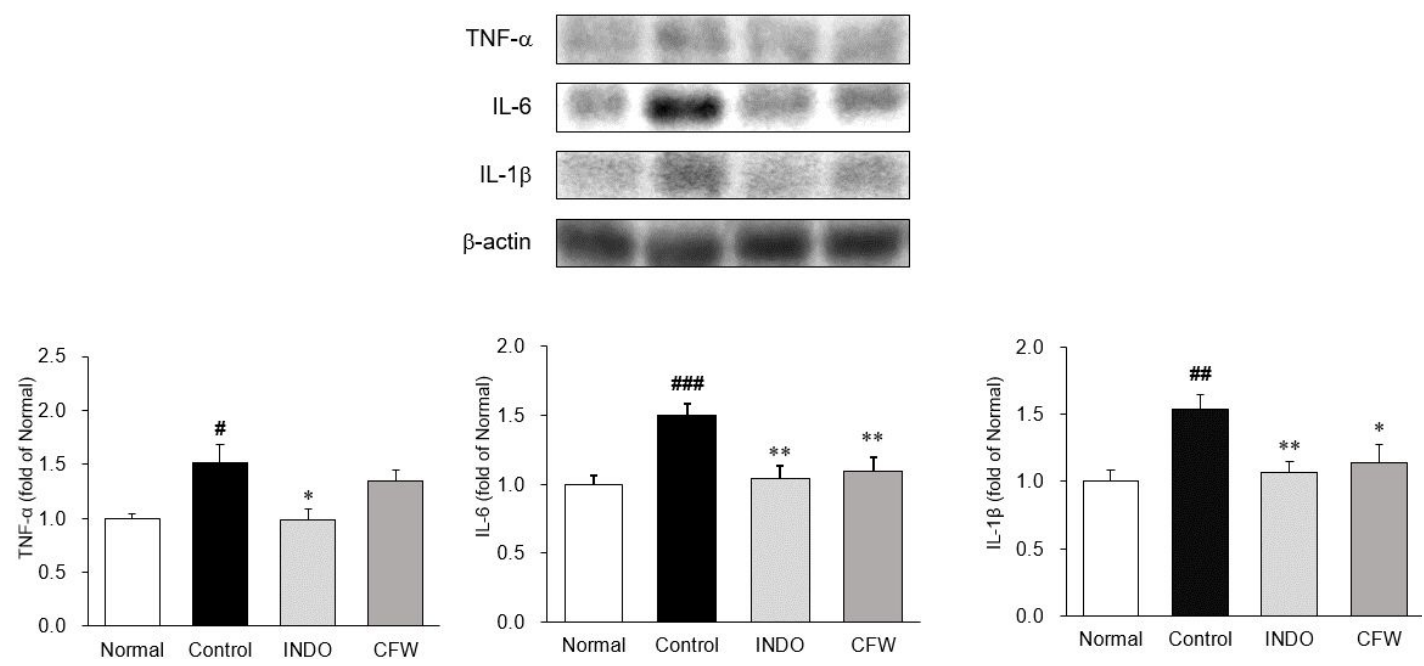

Fig. 6. Expression of inflammation-related cytokines in knee joint.

All data are expressed means \pm SD $(n=8)$.

Significance : ${ }^{*} p<0.05$, ${ }^{* *} p<0.01$ vs. control group and ${ }^{\#} p<0.05$, ${ }^{\#} p<0.01$, \#\#\# $p<0.001$ vs. normal group

Normal : normal rats, Control : MIA-induced osteoarthritis rats, INDO : MIA-induced osteoarthritis rats treated with indomethacin $5 \mathrm{mg} / \mathrm{kg}$ body weight, CFW : MIA-induced osteoarthritis rats treated with Corni Fructus water extract $200 \mathrm{mg} / \mathrm{kg}$ body weight

\section{IV. 고 찰}

골관절염은 연골세포의 소멸과 세포외기질의 손 상을 특징으로 하는 퇴행성 질환으로 체중부하가 걸리는 고관절 및 슬관절에 호발하며 ${ }^{28}$, 관절연골의 점진적인 손상, 연골의 변화, 골조직 형성 및 주변 조직의 변화 때문에 만성적인 염증과 통증을 유발 한다 ${ }^{29}$. 2008년 국민건강영양조사에 따르면 성인 중 $10.7 \%$ 가 골관절염을 않고 있으며 연령에 따라 비 율이 증가하여 80 대에는 $34.5 \%$ 에 이르는 것으로 나타나 ${ }^{8}$ 노년층이 골관절염의 주요 환자군을 형성한 다. 임상적으로는 비스테로이드성항염제(NSAIDs) 의 약물요법과 관절강 내 하이알루론산 등의 주사 요법이 흔히 사용되나 약물의 부작용 또는 지속적 인 염증성 통증으로 삶의 질이 점차 저하되는 경 우가 많고 각종 성인병과 함께 수술 합병증에 대 한 부담도 커서 골관절염 치료를 위해 한방 치료 를 찾는 환자들이 많은 실정이다. 한의학에서 골관
절염은 鶴膝風, 痺證, 歷節風, 脚氣 등의 범주로 보 았으며, 그 원인을 風寒濕 등의 外邪로 인하여 氣 血運行이 阻閉된 外因과, 노화에 따라 肝腎衰弱하 여 傷骨한 內因으로 분류하여 補肝腎陰虛 및 破疙 血을 위주로 치료한다 ${ }^{28}$. 산수유는 노화에 의한 각 종 질병 치료 처방에 빈용되는 구성 약재이며 장 기 복용할수록 효과가 큰 것으로 알려져 퇴행성질 환인 골관절염 예방 및 치료에 효과적일 것으로 판단되었기에 염증성 관절손상 동물모델을 이용하여 산수유 물추출물의 염증 억제 효과를 분석하였다.

먼저 MIA로 골관절염을 유발하여 뒷다리 체중 부하를 검사한 결과 관절 손상 후 정상군 대비 3개 그룹에서 모두 유의하게 증가하였다가 약물 투여 2주 후 대조군에 비해 INDO군과 CFW군에서 유 의하게 감소되는 것을 확인하였다. 이는 연골 손상 으로 인해 하체의 중심이 관절염이 유발되지 않은 건측으로 기울어지는 것을 이용하여 건측 체중부 하가 감소함으로써 관절염을 유발한 환측 다리로 
의 체중 지지가 증가한 것을 관찰하는 방법으로 손상받은 관절의 통증이 완화되었음을 의미한다. 즉, 산수유 물추출물이 골관절염으로 인한 통증을 경감시키는 효과가 있는 것으로 나타났다.

많은 연구에서 산화적 스트레스가 암, 당뇨병, 골관절염, 류마티스성 관절염, 죽상 동맥 경화증 및 만성 염증성 질환을 악화시킨다는 보고가 발표 되었다 ${ }^{30}$. 자유 라디칼 또는 활성산소종(Reactive oxygen species, ROS)은 정상적인 세포대사 동안 살아있는 유기체에 필수적인 산화 공정에서 생성 되는 매우 불안정한 분자 ${ }^{31}$ 로 과도하게 생성되거나 제거가 원활하지 못하였을 때 즉 산화제(oxidants) 와 산화 방지제(anti-oxidants)의 불균형을 야기하 게 되며 이는 산화적 스트레스(oxidative stress)를 유발하게 된다 ${ }^{32,33}$. 활성산소종은 세균감염 시 중요 한 살균 작용을 하지만, 과도하게 생산되었을 시 염증을 악화시키고 DNA 및 단백질과 같은 분자를 파괴하여 세포의 사멸을 유도하게 된다나. 또한 노 화과정에서 염증반응이 지속적으로 일어나면서 $\mathrm{iNOS}$ 유도에 따른 $\mathrm{NO}$ 의 대량 생성이 $\mathrm{ONOO}^{-}$의 생성을 더욱 증가시켜 세포 및 조직 손상을 가져오게 되 며 특히 $0 \mathrm{NOO}^{-}$의 독성은 $\mathrm{NO}$ 와 $\cdot \mathrm{O}_{2}{ }^{-}$보다 더 강한 것으로 알려져 있다 ${ }^{35}$. 본 연구에서는 골관절염의 증상을 악화시킬 수 있는 산화적 스트레스 바이오 마커인 ROS와 $\mathrm{ONOO}^{-}$를 측정하여 항산화 활성에 대한 산수유 물추출물의 효과를 관찰하였다. ROS 와 $\mathrm{ONOO}^{-}$는 INDO군과 $\mathrm{CFW}$ 군 모두에서 유의성 있게 감소하여 산수유 물추출물이 산화적 스트레 스를 효과적으로 억제함으로써 세포를 보호하고 관절연골의 염증 및 손상의 진행을 방어하는 것으 로 생각된다.

항산화 효과는 항산화 효소의 활성과 깊은 상관 관계가 있다. 항산화 효소는 자유 라디칼을 중화시 켜 자유 라디칼에 의한 손상을 최소화하게 된다 ${ }^{36}$. 염증조절 매개인자인 SOD (superoxide dismutase)는 산소 대사에 의하여 생성되는 superoxide $\operatorname{radical}\left(\mathrm{O}_{2}^{-}\right)$ 을 hydrogen peroxide $\left(\mathrm{H}_{2} \mathrm{O}_{2}\right)$ 로 전환시키며, catalase
와 glutathione peroxidase $(\mathrm{GPx})$ 에 의하여 hydrogen peroxide는 다시 $\mathrm{H}_{2} \mathrm{O}$ 와 $\mathrm{O}_{2}$ 로 분해하는 과정을 통 해 활성산소를 제거하여 세포 손상을 방지한다 ${ }^{37.38}$. 골관절염을 유발한 관절조직에서 이러한 항산화 효소 단백질을 분석한 결과, IND0군과 $\mathrm{CFW}$ 군에 서 SOD의 발현량이 증가하였으나 유의성은 없었 고, catalase와 $\mathrm{GPx}-1 / 2$ 는 IND0군과 $\mathrm{CFW}$ 군에서 모두 유의성 있게 증가하였다. 이는 산수유 추출물 이 항산화 단백질의 생성을 증가시켜 산화적 스트 레스로 인한 관절 연골의 손상의 진행을 억제하는 효과를 보이는 것으로 판단된다.

Nuclear factor-kappa B(NF- $\mathrm{B})$ 는 염증 매개물 질의 생성을 조절하는 전사인자로 정상 상태에서 는 세포질에서 $\mathrm{I \kappa B}-\mathrm{a}$ 단백질과 결합하여 불활성 상태로 세포질에 존재하다가 외부 자극에 의하여 IKB- $a$ 가 인산화되면 p65 단백질이 세포 핵 내로 이동하여 전사가 이루어지게 되고, 이 때, 염증성 매개인자인 cyclooxygenase-2(COX-2)와 inducible nitric oxide synthases(iNOS) 그리고 염증성 cytokine 인 TNF-a, IL-1ß, IL-6 등을 생성하게 된다. 즉, $\mathrm{NF}-\kappa \mathrm{B}$ 는 염증매개 cytokine의 발현에 중요한 역할 을 담당하는 경로로 알려져 있으며 $39,40, \mathrm{NF}-\kappa \mathrm{B}$ 의 활성 억제와 cytokine의 생성 억제는 염증성 관절 염 치료와 예방에 있어 중요한 부분이 된다. 본 연 구에서는 NF-KB의 활성을 억제함으로 인해 염증 성 매개인자인 $\mathrm{COX}-2$ 의 발현을 유의하게 억제시

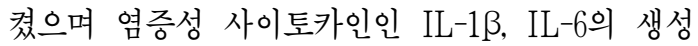
이 산수유 투여에 의해 유의하게 감소하였다. 특히 $\mathrm{NF}-\mathrm{\kappa B}$ 의 활성 억제는 INDO군보다 $\mathrm{CFW}$ 군에서 더 효과적으로 억제되는 것을 확인하였다.

이와 같은 결과를 종합하여 볼 때 산수유 추출 물은 NF- $\mathrm{KB}$ 의 활성 억제를 통한 염증성 단백질의 발현을 감소시켜 골관절염의 염증 개선 및 연골 파괴의 진행을 억제하였으며 이는 골관절염의 통 증 감소와 회복을 도운 것으로 판단되어지며 또한, 항산화효소 단백질의 증가를 통해 산화적 스트레 스를 감소시켜 관절 보호 효과를 발휘하는 것으로 
사료된다.

\section{V. 결 론}

본 연구에서는 산수유의 골관절염에 대한 염증 억제 효과를 과학적으로 검증하기 위하여 MIA로 골 관절염을 유발 후 2주 동안 산수유 $200 \mathrm{mg} / \mathrm{kg} / \mathrm{day}$ 를 투여한 후 체중부하 측정, 혈액 분석 및 관절 조직 내 단백질 발현량을 분석한 결과, 다음과 같 은 결론을 얻었다.

1. 체중부하 측정 시 정상군에 비해 대조군에서 유 의하게 상승하였으며, 산수유 투여로 인해 유의 하게 감소하였다.

2. 산수유 투여는 관절 조직 내 산화적 스트레스 마커인 ROS와 $\mathrm{ONOO}^{-}$를 대조군에 비해 유의 하게 감소시켰다.

3. 산수유 투여군은 Catalase와 GPx-1/2와 같은 항 산화 효소 단백질을 유의하게 증가하였다.

4. 산수유 투여는 NF- $\mathrm{kB}$ 의 활성을 유의하게 억제 시켰으며 이는 염증성 매개인자인 $\mathrm{COX}-2$ 를 유 의하게 감소시켰고, IL-6와 IL-1 같은 염증성 사이토카인을 유의하게 감소시켰다.

이상의 결과들로 보아 산수유는 골관절염 동물 모델에서 산화적 스트레스 및 항산화 효소 단백질 을 상승시켜 항산화 효과를 발휘하였으며 $\mathrm{NF}-\kappa \mathrm{B}$ 비활성을 통한 염증인자들을 억제함으로서 골관절 염에서의 관절 보호 효과를 발휘하는 것으로 나타 났다. 이는 산수유가 골관절염 치료를 위한 소재로 적극 활용될 수 있음을 시사하고 있다.

\section{감사의 글}

본 연구는 2012년 대구한의대학교 교내학술연구 비지원(기린연구 과제번호 2012-901-31)에 의해 연
구되었습니다.

\section{참고문헌}

1. The Society of Korean Medicine Rehabilitation. Oriental rehabilitation medicine. $2^{\text {nd }}$ rev. Seoul: Koonja; 2005, p. 84, 97.

2. Park JS, Lee HJ, Lee DY, Jo HS, Jeong JH, Kim DH, et al. Chondroprotective effects of wogonin in experimental models of osteoarthritis in vitro and in vivo. Biomol Ther 2015:23(5): 442-8.

3. Braza-Boils A, Ferrandiz ML, Terencio MC, Alcaraz MJ. Analysis of early biochemical markers and regulation by tin protoporphyrin IX in a model of spontaneous osteoarthritis. Exp Gerontol 2012;47(5): 406-9.

4. Choi DJ, Choi SI, Choi BR, Lee YS, Lee DY, Kim GS. Cartilage protective and anti-analgesic effects of ALM16 on monosodium iodoacetate induced osteoarthritis in rats. BMC Complement Altern Med 2019;19(1):325.

5. Greene MA, Loeser RF. Aging-related inflammation in osteoarthritis. Osteoarthritis Cartilage 2015:23(11) :1966-71.

6. Kim YJ. Effects of Curcuma longa Rhizoma on MIA-induced Osteoarthritis in Rat Model. $J$ Korean Med 2019;40(3):35-58.

7. Park S, Kim YS, Lee D, Kwon Y, Park J, Lee SY, et al. Efficacy and safety of HT008 and glucosamine sulfate in the treatment of knee osteoarthritis: a randomized double-blind trial. Kor J Herbology 2014;29(4):45-52.

8. Jhun HJ, Ahn K, Lee SC. Estimation of the prevalence of asteoarthritis in Korean adults based on the data from the fourth Korea national health and nutrition examination survey. 
Anesth Pain Med 2010:5(3):201-6.

9. Yun JH. Osteoarthritis update. J Korean Med 2012;82(2):170-4.

10. Liu CC. Anti-Oxidants and Anti-inflammation Effects of Geongangbuja-tang. Daejoen: Graduate school, Daejoen Univ; 2011.

11. Choi WJ. The antioxidative and anti-inflammatory effects of lophatheri extracts for herbal-acupuncture via reducing iNOS synthesis induced by LPS in RAW 264.7 cell. Iksan: Graduated school, Wonkwong Univ; 2010.

12. Park SD. Effect of Cervi Pantotrichum Cornu herbal acupuncture on protease activities anti-oxidant in rheumatoid arthritis rats. The Journal of Korean Acupuncture and Moxibustion Society 2002;19(2):51-64.

13. An SS, Heo DS. Effects of Kyejiinsam-tang in MIA-induced Osteoarthritis Rats. Journal of Korean Med 2013:34(3):69-85.

14. Kim YJ. Effects of Curcuma longa Rhizoma on MIA-induced Osteoarthritis in Rat Model. $J$ Korean Med 2019;40(3):35-58.

15. Kim EN, Roh SS, Jeong GS. Inhibitory Effect of Sparassis crispa(Wulf.) Extract on Monosodium Iodacetate Induced Osteoarthritis. Journal of Korean Pharmacogn 2018;49(3) :262-9.

16. Kim IL, Kim HC, Guk YB, Park SJ, Park YK, Park JH, et al. Bonchohak. 2rd rev. Seoul: Yunglimsa; 2011, p. 688-9.

17. Sung YH, Chang HK, Kim SE, Kim YM, Seo $\mathrm{JH}$, Shin MC, et al. Anti-inflammatory and analgesic effects of the aqueous extract of corni fructus in murine RAW 264.7 macrophage cells. $J$ Med Food 2009;12(4) :788-95.

18. Kang DG, Choi DH, Lee JK, Lee YJ, Moon MK, Yang SN, et al. Endothelial NO/cGMPdependent vascular relaxation of cornuside isolated from the fruit of Cornus officinalis. Planta Med 2007;73(14) :1436-40.

19. Kim KS, Lee BR, Yang GY, An TW, Yim YK. Effects of the Herbal-Acupuncture with Corni Fructus Extract at Eumgok on Osteoporosis in Ovariectomized Mice. Korean Journal of Acupuncture 2010:27(1):63-85.

20. Shin JH, Cha GY, Kim HJ, Hwang JH, Han $\mathrm{KH}$, Seo HJ, et al. Exmination of Anti-Obesity Effect of RegionalSpecial Natural Products of Anthrisci radix, Psoraleaesemen, Siegesbeckiae herba and Corni fructus. KSBB Journal 2009; $24(6): 549-55$.

21. Park EB, Kim HS, Shin SY, Ji IA, Kim JH, Kim SG, et al. Antioxidative activity of Cornus Officaianalis extract obtained by four different extraction techniques. Journal of life Science 2012;22(11) :1507-14.

22. Kim OK. Antidiabetic and antioxidative effects of corni fructus in streptozotocin-induced diabetic rats. J Korean Oil Chemists' Soc 2005:22(2): 157-67.

23. Yamabe N, Noh JS, Park CH, Kang KS, Shibahara N, Tanaka T, et al. Evaluation of loganin, iridoid glycoside from Coni Fructus on hepatic and renal glucoilipotoxicity and inflammation in typ 2 diabetic $\mathrm{db} / \mathrm{db}$ mice. EUR J Pharmacol 2010 Dec 1;648(1-3):179-87.

24. Kwon SH, Kim HC, Lee SY, Jang CG. Loganin improves learning and momory impairments induced by scopolamine in mic. EUR $J$ Pharmacol 2009; $619(1-3): 44-9$.

25. Korean Acupuncture \& Moxibustion Society. The Acupuncture and Moxibustion Medicine. Paju: Jibmoondang; 2012.

26. Ali SF, LeBel CP, Bondy SC. Reactive oxygen species formation as a biomarker of methylmercury 
and trimethyltin neurotoxicity. Neurotoxicology 1992;13(3):637-48.

27. Kooy NW, Royall JA, Ischiropoulos H, Beckman JS. Peroxynitrite-mediated oxidation of dihydrorhodamine 123. Free Radical Biology and Medicine 1994; 16(2) :149-56.

28. Korean Acupuncture \& Moxibustion Medicine Society. Acupuncture Medicine. Seoul: Hanmibook; 2016, p. 537-68.

29. Johnston SA. Joint Anatomy, Physiology and Pathobiology. Vet Clin North Am Samll Anim Pract 1997;27(4):699-723.

30. Elisha IL, Dzoyem JP, McGaw LJ, Botha FS, Eloff JN. The anti-arthritic, anti-inflammatory, antioxidant activity and relationships with total phenolics and total flavonoids of nine South African plants used traditionally to treat arthritis. BMC Complement Altern Med 2016:16:307.

31. Gupta RK, Patel AK, Shah N, Chaudhary AK, Jha UK, Yadav UC, et al. Oxidative stress and antioxidants in disease and cancer: a review. Asian Pac J Cancer Prev 2014;15(11): $4405-9$.

32. Valko M, Leibfritz D, Moncol J, Cronin MT, Mazur M, Telser J. Free radicals and antioxidants in normal physiological functions and human disease. Int $J$ Biochem Cell Biol 2007:39(1): 44-84.

33. Spector A. Oxidative Stress and Disease. J Ocul
Pharmacol Ther 2000;16(2):193-201.

34. Bedard K, Krause KH. The NOX family of ROS-generating NADPH Oxidases: Physiology and Pathophysiology. Physiol Rev 2007:87(1) :245-313.

35. Hann GPMM, PAquay JBG, Korthouwer REM, Bast A. Peroxynitrite scavenging by flavonoids. Biochem Biophy Res Commu 1997;236(3):591-3. 36. Wang W, Gao C, Ren L, Luo Y. The Effect of Longwave Ultraviolet Light Radiation on Dendrolimus tabulaeformis Antioxidant and Detoxifying Enzymes. Insects 2019;11(1). pii: E1.

37. Van Raamsdonk JM, Hekimi S. Superoxide dismutase is dispensable for normal animal lifespan. Proc Natl Acad Sci USA 2012;109(15) :5785-90.

38. Preiser JC. Oxidative stress. JPEN J Parenter Enteral Nutr 2012;36(2):147-54.

39. Park SH, Lee HJ, Ryu JH, Lee SY, Shin HD, Hong $\mathrm{JH}$, et al. Effects of Silibinin and resveratol on degradation of $\mathrm{I} \kappa \mathrm{B}$ and translocation of $\mathrm{NF}-\kappa \mathrm{B}$ p65 induced by tumor necrosis factor- $\mathrm{a}$ in cultured airway epithelial cells. Yakhak Hoji 2014;58(1):1-6.

40. Lee SM, Kim YK, Hwang YH, Lee CH, Lee HS, Lee CT, et al. Role of PI3Iк/Akt pathway in the activation of IIкB/NF-кB pathway in lung epithelial cells. Tuberculosis and Respiratory Diseases 2003;54(5):551-62. 